\title{
Chlorophyll and carbohydrates in Arachis pintoi plants under influence of water regimes and nitrogen fertilization
}

\section{Rita Manuele Porto Sales ${ }^{1}$, Daniela Deitos Fries ${ }^{2}$, Aureliano José Vieira Pires ${ }^{3}$, Paulo Bonomo², lasminy Silva Santos ${ }^{4}$, Cleide Nascimento Campos ${ }^{4}$, Paulo Henrique Rodrigues Brito ${ }^{4}$, Mateus Santos Brito ${ }^{4}$}

\author{
${ }^{1}$ Mestranda em Zootecnia/UESB, Itapetinga, BA, Brazil. \\ ${ }^{2}$ Departamento de Estudos Básicos e Instrumentais/UESB, Itapetinga, BA, Brazil. \\ ${ }^{3}$ Departamento de Tecnologia Rural e Animal/UESB, Itapetinga, BA, Brazil. Researcher at CNPq \\ ${ }^{4}$ Graduando (a) em Ciências Biológicas/UESB, Itapetinga, BA, Brazil.
}

\begin{abstract}
In this experiment the chlorophyll and carbohydrate contents of Arachis pintoi were evaluated to verify if the presence of nitrogen in the soil could contribute to the effectiveness of the establishment of this legume. The design was completely randomized, in a $4 \times 4$ factorial arrangement, with four $\mathrm{N}$ rates $\left(0,40,80\right.$ and $\left.120 \mathrm{~kg} \mathrm{ha}^{-1}\right)$ and four irrigation levels $(25,50,75$ and $100 \%$ of field capacity), with four replications. The biochemical evaluations of chlorophylls $a$ and $b$ and total chlorophyll and total soluble sugars, sucrose and starch were performed. The highest contents of chlorophyll $a$ and $b$ and total chlorophyll in leaves were found at the dose of $120 \mathrm{~kg} \mathrm{ha}^{-1}$. The water regime of $25 \%$ of field capacity was responsible for the lowest content of reducing sugars and total soluble sugars in leaves, stolons and roots. In the roots, the sucrose contents were higher in these conditions, which can be associated with a slight tolerance of the plant to water stress. The water deficiency was responsible for the decrease of reducing sugars and total $\mathrm{N}$ in the whole plant and positively influenced the levels of chlorophyll and sugars in the stolon, promoting growth, especially of shoots, at the beginning of establishment.
\end{abstract}

Key Words: development, field capacity, legume, starch, sugars

\section{Introduction}

The use of pastures in ruminant production is cheaper for the farmer, and in the last years, has promoted great advances in productivity. In addition to the economic aspect, debates on problems concerning the quality of animal-origin products, environmental impacts and the animal welfare have intensified. The use of forage legumes has been an alternative for a balanced, sustainable and ecologically correct production (Silva, 2008).

Arachis pintoi cv. Belmonte is a very aggressive creeping leguminous plant as regards the soil cover due to its stolons, which penetrate into the soil by root nodules, and present protected growth spots (Jank et al., 2005). These features allow its good adaptability in association with aggressive grasses.

One of the greatest contributions of Arachis pintoi to the production system is its atmospheric nitrogen $(\mathrm{N})$ fixation potential, which makes it a forage of better nutritional value and improves the soil fertility (Miranda et al., 2003). Thus, the establishment of this legume is considered very slow and is one of the main limitations of this species (Ramos et al., 2010).
Another common limiting factor to forage growth is water availability. In such condition, tolerant plants show morphologic and metabolic alterations, which contribute to their survival in these environments (Blum, 1996; Xiao et al., 2009), as well as alterations in the end products of photosynthesis, such as starch and saccharose (Reddy et al., 2004), inevitably affecting the partition of photoassimilates to the whole plant.

Given these limitations, the management must be adequate so as to promote the establishment of forage peanut in an intercropping with grasses. Bearing in mind that $\mathrm{N}$ determines forage growth and production speed (Silva et al., 2008) for being a part of important cell components such as chlorophyll, proteins and nucleic acids, required in large amounts and limiting to plant growth (Taiz \& Zeiger, 2009), nitrogen fertilization can be a mechanism of acceleration of the initial growth of leguminous plants, allowing for quick establishment and tolerance to dry periods.

The objective was to evaluate the chlorophyll and carbohydrate contents in Arachis pintoi cultivated under different water availabilities and nitrogen fertility. 


\section{Material and Methods}

The experiment was conducted in a greenhouse of the Forage and Pasture Department of Universidade Estadual do Sudoeste da Bahia, UESB, campus Juvino Oliveira, located in the municipality of Itapetinga - BA, Brazil, from July to October 2010. The experimental design adopted was completely randomized, in a $4 \times 4$ randomized design: four doses of nitrogen $\left(0,40,80\right.$ and $\left.120 \mathrm{~kg} \mathrm{ha}^{-1}\right)$ and four water regimes $(25,50,75$ and $100 \%$ of field capacity (FC)), with four replications, totaling 64 pots with capacity of $10 \mathrm{dm}^{-3}$.

The soil used was collected from the 0-20 deep layer in the campus of Universidade Estadual do Sudoeste da Bahia, UESB. After the soil was filtered through a $4.0 \mathrm{~mm}$ screen sieve, pots were filled and a sample was collected for physical and chemical analysis. As physical characteristics, the soil presented loamy sand texture, with $11 \%$ clay, $86 \%$ sand and 3\% silt, classified as an orthic Quartzarenic Neosol (Embrapa, 1999). The chemical attributes of the soil presented the following results: $\mathrm{pH}$ in water $=5.7$; $\mathrm{P}=37 \mathrm{mg} \mathrm{dm}^{-3}$, in Mehlich 1 extractor; $\mathrm{K}=0.30 \mathrm{cmol}_{\mathrm{c}} \mathrm{dm}^{-3}$; $\mathrm{Ca}=3.0 \mathrm{cmol}_{\mathrm{c}} \mathrm{dm}^{-3} ; \mathrm{Mg}=1.4 \mathrm{cmol}_{\mathrm{c}} \mathrm{dm}^{-3} ; \mathrm{Al}=0.1 \mathrm{cmol}_{\mathrm{c}} \mathrm{dm}^{-3}$; $\mathrm{H}=2.1 \mathrm{cmol}_{\mathrm{c}} \mathrm{dm}^{-3}$; saturation of bases $=4.7 \mathrm{cmol}_{\mathrm{c}} \mathrm{dm}^{-3} ; \mathrm{T}=$ $6.9 \mathrm{cmol}_{\mathrm{c}} \mathrm{dm}^{-3} ; \mathrm{V}=68 \%$; and organic matter $=29 \mathrm{~g} \mathrm{dm}^{-3}$.

According to the recommendations of the Soil Fertility Committee of Minas Gerais State (Alvarez V. \& Ribeiro, 1999), there was no need for liming the soil, since the base saturation value in the layer collected was at $68 \%$.

Arachis pintoi seedlings were produced from stolon cuttings from mother plants obtained in campus Juvino Oliveira. Cuttings were planted with a node, and after shooting plants were thinned, keeping four plants per pot. During the growth period, the water level in the soil was kept near the FC, and all pots were weighed daily.

To determine field capacity, all pots with dry soil were weighed, soaked with water and after the excess was drained they were weighed again. Field capacity was determined by the difference between dry and wet weight; maximum water retention was at around $20 \%$. The determination of water reposition for each water regime was calculated in relation to this difference.

Nitrogen doses of $0,40,80$ and $120 \mathrm{~kg} \cdot \mathrm{ha}^{-1}$, corresponding to $0.44,0.89$ and $1.33 \mathrm{~g}$ of urea $(44 \% \mathrm{~N})$ per pot were split in two applications: the first occurred on the day cuttings were planted, and the second 20 days after. The average temperature recorded during the experimental period was $28.5^{\circ} \mathrm{C}$.

After a growth period (70 days), plants were subjected to the water regimes of $25,50,75$ and $100 \%$ of $\mathrm{FC}$ for a period of 15 days, determined by the senescence of plants subjected to the $25 \% \mathrm{FC}$ regime. After this stress period, pots were disassembled by continuous washing with running water and plants were dissected into root, leaves and stolons, and biochemical evaluations were performed.

For the extraction of chlorophylls $a$ and $b, 200 \mathrm{mg}$ fresh material of three leaves per replication were collected and immediately macerated in $80 \%$ cold acetone, under lowlight conditions. Next, the solution was filtered, completing the volume to $20 \mathrm{~mL}$ and quantification was performed by spectrophotometry at 645 and $663 \mathrm{~nm}$. The calculation of chlorophylls was done through the following formulas (Arnon, 1949): total chlorophyll $=(20.2 \times$ Abs645 $)+(8.02$ $\times$ Abs663); chlorophyll $a=(12.7 \times$ Abs663 $)-(2.69 \times$ Abs645 $)$; and chlorophyll $b=(22.9 \times$ Abs645) $-(4.68 \times$ Abs663 $)$.

Soluble carbohydrates were extracted by homogenizing $200 \mathrm{mg}$ of dry mass of leaves, stalk and roots in $12 \mathrm{~mL}$ $\mathrm{K}_{2} \mathrm{PO}_{4}$ buffer solution (100 mM; pH 7.0), followed by centrifugation at $4000 \mathrm{rpm}$ for $20 \mathrm{~min}$ and collection of the supernatant. The process was performed two more times and the supernatants were combined. For extraction of starch, the pellet was re-suspended with $5.0 \mathrm{~mL}$ of potassium acetate buffer (200 mM; pH 4.8) and placed in a water bath $\left(100{ }^{\circ} \mathrm{C}\right)$ for five minutes. After, $30 \mathrm{~mL}$ of enzyme amyloglucosidase were added, incubating it in a water bath at $40{ }^{\circ} \mathrm{C}$ for two hours under agitation. After centrifugation at $4000 \mathrm{rpm}$ for 20 minutes, the supernatant was collected and the volume was completed to $15 \mathrm{~mL}$. Total soluble sugars and starch were quantified by the anthrone method (Dische, 1962), and reducing sugars by the dinitrosalicylic acid (DNS) method (Miller, 1959)

The data were subjected to multiple regression analysis with the selection of a linear model, whose coefficients were evaluated by the $t$ test, adopting $\alpha=0.05$. Initially, an equation with linear, quadratic and cubic effects, in addition to the effects of interaction of factors water regime and nitrogen doses, was tested. For the model chosen, the coefficient of determination was presented to evaluate the model adequacy.

\section{Results and Discussion}

Nitrogen doses affected the chlorophyll contents linearly; maximum contents of total chlorophyll and chlorophylls $a$ and $b\left(8.4,5.3\right.$ and $3.2 \mathrm{mg} . \mathrm{g}^{-1} \mathrm{DM}$, respectively) were verified with the dose of $120 \mathrm{~kg}^{-h^{-1}}$ (Figure 1). Benett et al. (2008) also verified linear increase in the chlorophyll levels as the $\mathrm{N}$ levels applied were increased, correlating the concentration of chlorophyll with the concentration of nitrogen in the leaves, and consequently with plant nutrition and production. 

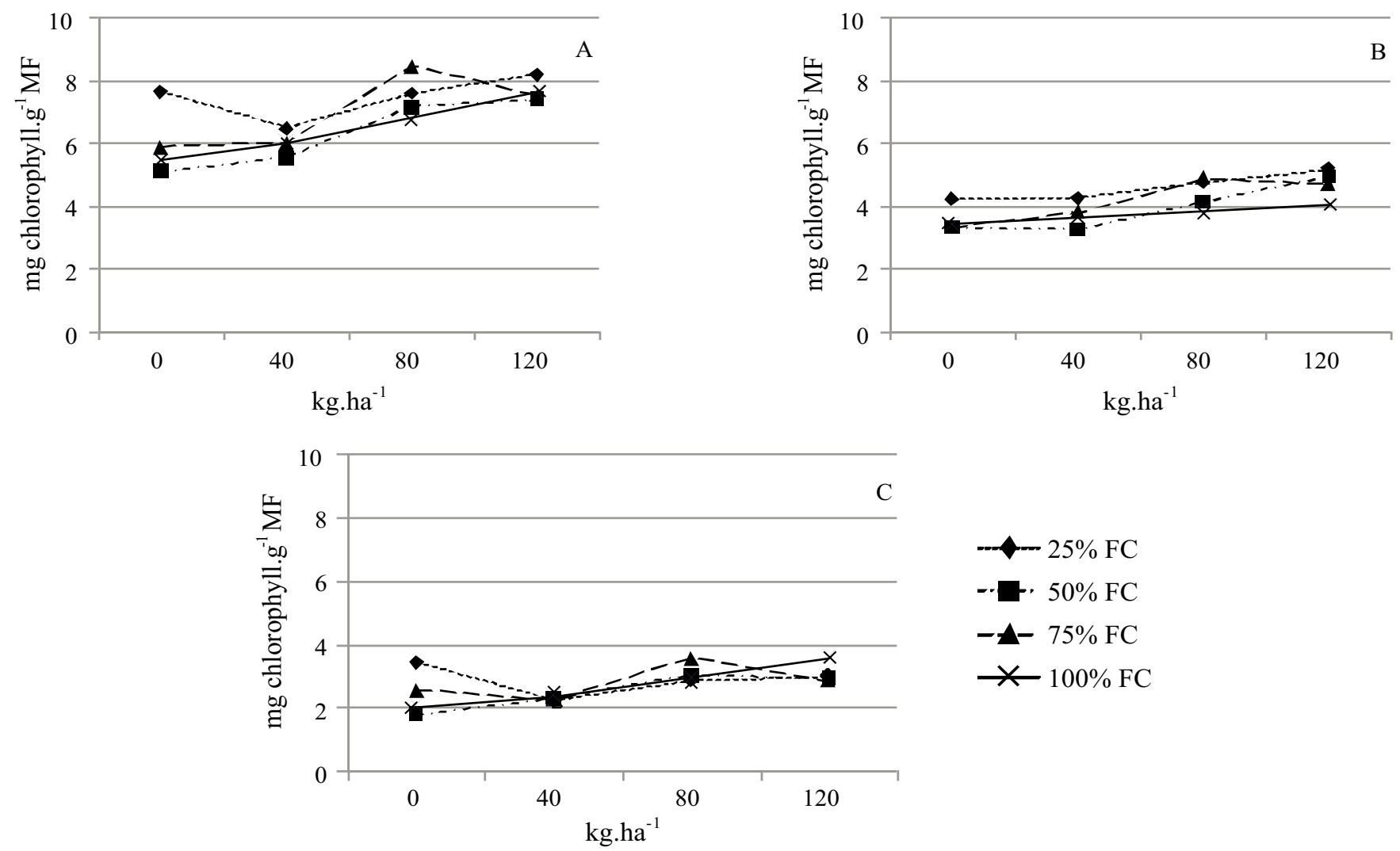

LM - leaf mass; FC - field capacity.

Figure 1 - Total chlorophyll (A) and chlorophylls $a(\mathrm{~B})$ and $b(\mathrm{C})$ in the leaves of Arachis pintoi cv. Belmonte, cultivated under different water regimes and nitrogen doses, according to the following equations: total chlorophyll $=6.384+0.0169 * \mathrm{~N}-0.00939 \mathrm{FC}$ $(* \mathrm{P}<0.05)$, with $\mathrm{R}^{2}=0.82$; chlorophyll $\mathrm{a}=4.0475+0.0102 * \mathrm{~N}-0.00903 \mathrm{FC}(* \mathrm{P}<0.05)$, with $\mathrm{R}^{2}=0.89$; and chlorophyll $\mathrm{b}=2.338$ $+0.00681 * \mathrm{~N}-0.000364 \mathrm{FC}(* \mathrm{P}<0.05)$, with $\mathrm{R}^{2}=0.77$.

In addition to the protein synthesis in plants, $\mathrm{N}$ is the essential part of several cell components such as chlorophyll and the enzyme ribulose bisphosphate carboxylase/ oxygenase (Rubisco), whose concentrations in the leaf directly affect the photosynthetic efficiency of the plant (Taiz \& Zeiger, 2009).

Under water stress conditions, especially when coupled to excessive heat or radiation, chlorophyll is degraded (Havaux \&Tardy, 1999), and the total content of this pigment in leaves can be an indicative of stress in plants (Gratani \& Varone, 2004; Chylinski et al., 2007). In the present study, no reduction was verified in the total chlorophyll contents according to the water stress, which can be due to the fact that, especially at $25 \%$ of FC, most of the leaves dried without presenting chlorosis and the leaves used for analysis were still green.

The total soluble sugar (TSS) and reducing sugar (RS) contents of the leaf responded linearly to the water regime (Figures 2A and B). According to the equations obtained for the variables, the lowest contents obtained for RS and TSS were 56.4 and $61.3 \mathrm{mg} . \mathrm{g}^{-1} \mathrm{DM}$, respectively, for the water regime of $25 \%$ of FC; and the highest contents were
67.8 and $82.5 \mathrm{mg} . \mathrm{g}^{-1} \mathrm{DM}$, respectively, for the water regime of $100 \% \mathrm{FC}$.

Because the carbohydrates in the leaves are produced by photosynthesis, they are directly affected by the water stress (Valliyodan \& Nguyen, 2006), so it is common for the concentrations of these carbohydrates to vary according to the water regime.

However, because the leaf is a source organ, carbohydrates do not remain in it at large amounts, because they are being produced and transported to other organs (Taiz \& Zeiger, 2009). This can explain the variation, especially of saccharose, observed in the leaf (Figure 2C).

According to Chaves \& Oliveira (2004), water stress can lead to increase in (under moderate stress) or stabilization (severe stress) of the concentration of soluble sugars in the leaves, despite the low carbon (C) assimilation, because the growth and exportation of photoassimilates are also inhibited.

The total soluble sugar (TSS) content in the stolon responded to the interaction between $\mathrm{N}$ doses and water regime (Figure 3A), showing its lowest level, $109.7 \mathrm{mg} \cdot \mathrm{g}^{-1}$ $\mathrm{DM}$ at the combination of absence of $\mathrm{N}$ and a water regime 

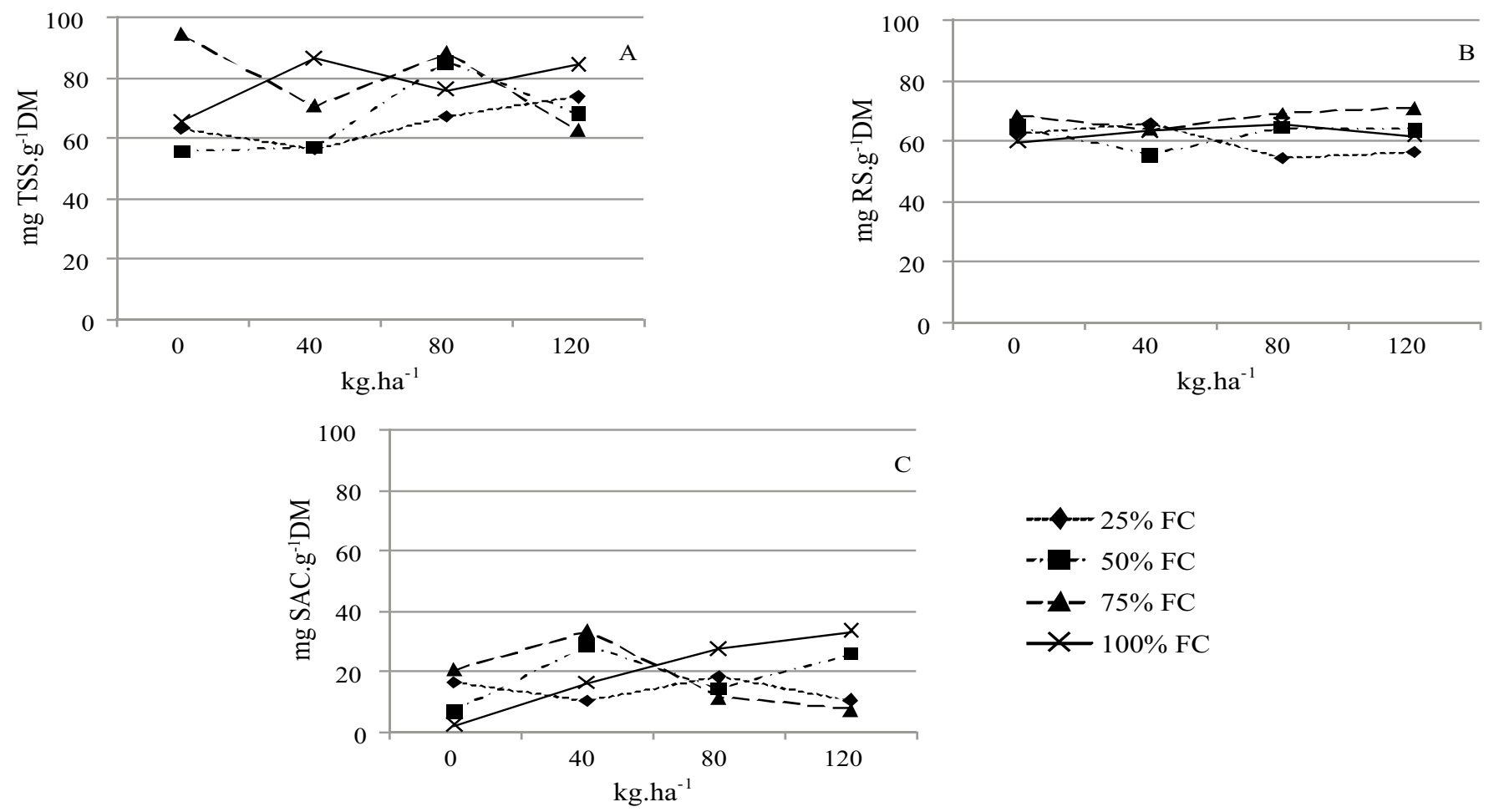

DM - dry matter; FC - field capacity.

Figure 2 - Total soluble sugars (TSS; A), reducing sugars (RS; B) and saccharose (SAC; C) in the leaves of Arachis pintoi cv. Belmonte, cultivated under different water regimes and nitrogen doses, according to the following equations: $\mathrm{TSS}=56.181+0.0484 \mathrm{~N}+$ $0.205 * \mathrm{FC}(* \mathrm{P}<0.05)$, with $\mathrm{R}^{2}=0.31$; and $\mathrm{RS}=54.434+0.0452 \mathrm{~N}+0.0795 * \mathrm{FC}(* \mathrm{P}<0.05)$, with $\mathrm{R}^{2}=0.53$.
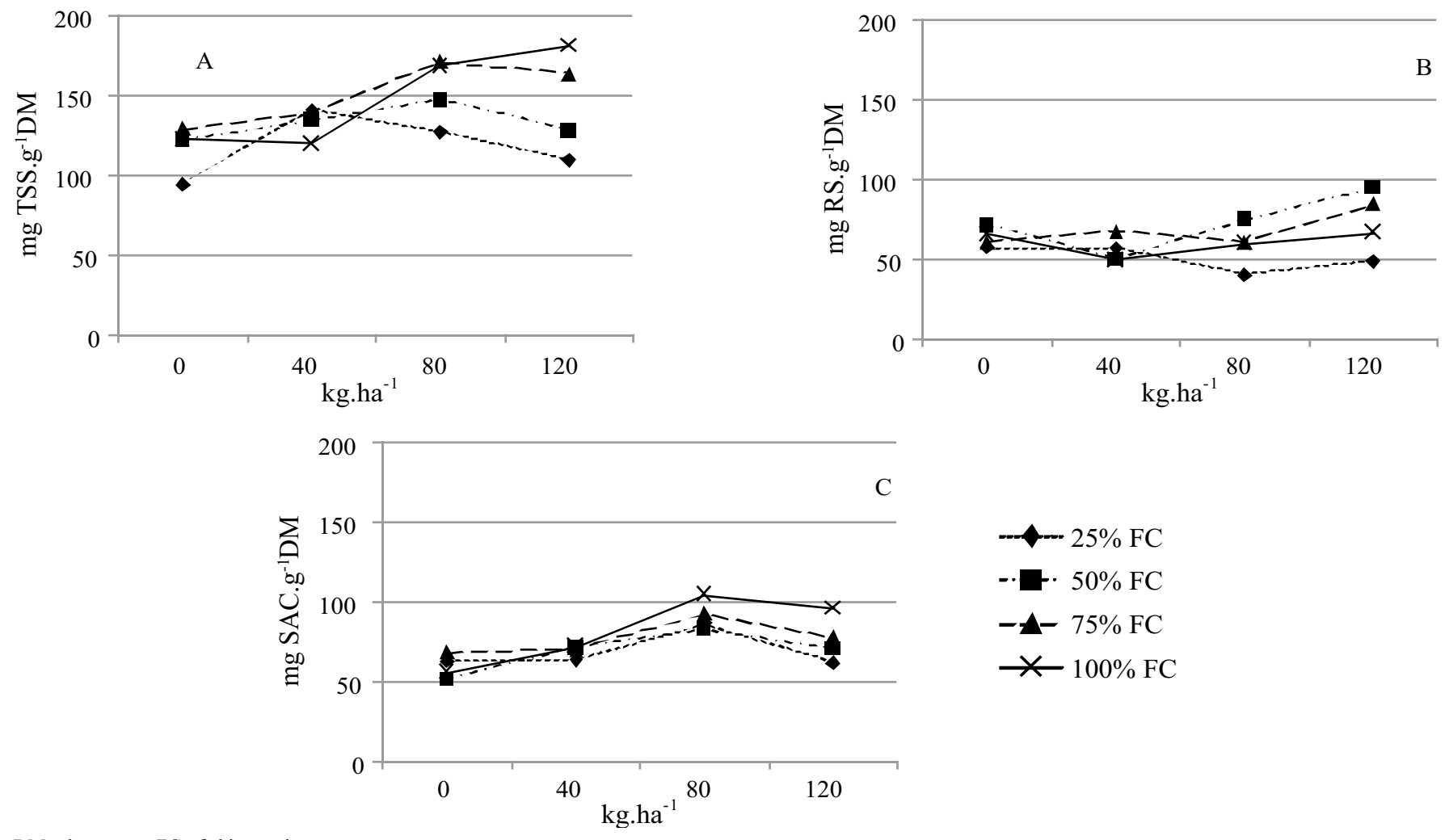

DM - dry matter; FC - field capacity.

Figure 3 - Total soluble sugars (TSS; A), reducing sugars (RS; B) and saccharose (SAC; C) in the stolons of Arachis pintoi cv. Belmonte, cultivated under different water regimes and nitrogen doses, according to the following equations: TSS $=91.595+0.299 \mathrm{~N}-$ $0.00382 * \mathrm{~N}^{2}+0.898 * \mathrm{FC}-0.00697 * \mathrm{FC}^{2}+0.0068 \mathrm{NFC}(* \mathrm{P}<0.05)$, with $\mathrm{R}^{2}=0.79$; and $\mathrm{RS}=19.900-0.342 * \mathrm{~N}+0.00352 * \mathrm{~N}^{2}+$ $1.596 * \mathrm{FC}-0.0119 * \mathrm{FC}^{2}\left({ }^{*} \mathrm{P}<0.05\right)$, with $\mathrm{R}^{2}=0.60$. 
of $25 \%$ of field capacity, and its highest content, 174.1 mg. $\mathrm{g}^{-1} \mathrm{DM}$, at the association of $120 \mathrm{~kg} \cdot \mathrm{ha}^{-1}$ and water regime of $100 \%$ FC. Reducing sugars (RS) in the stolon, in turn, responded quadratically to the $\mathrm{N}$ doses and water regime (Figure 3B), wherein the dose of $120 \mathrm{~kg} \cdot \mathrm{ha}^{-1}$ and the water regime from 65 to $70 \%$ of field capacity resulted in

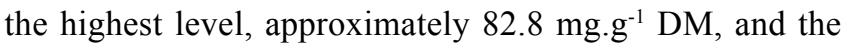
lowest contents ( $44.0 \mathrm{mg} . \mathrm{g}^{-1} \mathrm{DM}$ stolon) were observed the doses from 40 to $50 \mathrm{~kg} \cdot \mathrm{ha}^{-1}$ and in the water regime of $25 \%$ of field capacity.

High levels of TSS in the form of saccharose in the stalk (Figure 3C) demonstrate the photoassimilate transportation function of this organ. At the same time, greater concentrations of TSS and saccharose under more appropriate water conditions demonstrate high photosynthetic activity. According to Reddy et al. (2004), water deficiency affects the partition of photoassimilates to the whole plant due to changes in the relationship between some of the end products of photosynthesis, such as starch and saccharose.

The total soluble sugar and reducing sugar contents in the roots responded quadratically to the $\mathrm{N}$ doses and to the water regime (Figure $4 \mathrm{~A}$ and $\mathrm{B}$ ). According to the equations, the water regime of $25 \%$ of $\mathrm{FC}$ provided the lowest levels of RS and TSS in the roots, in which the
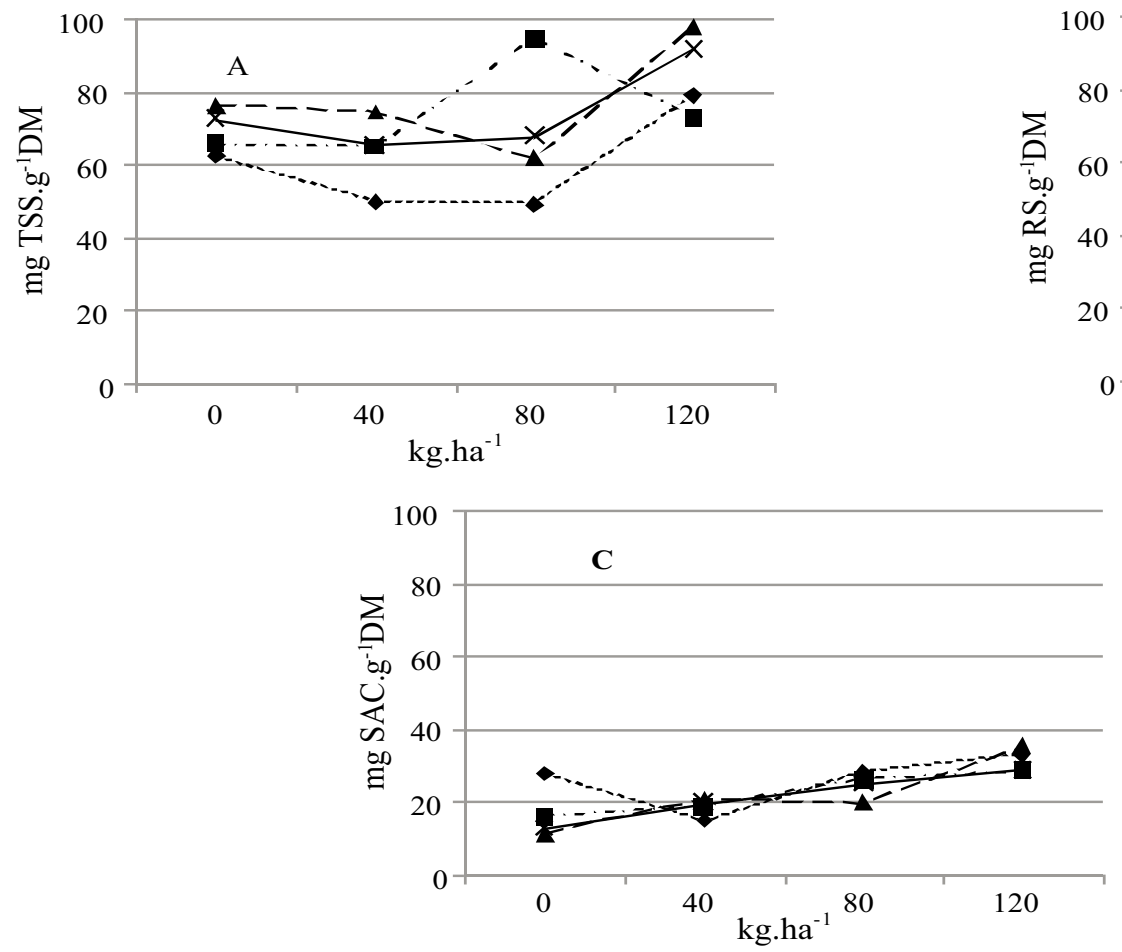

combination of the dose of $65 \mathrm{~kg} \cdot \mathrm{ha}^{-1} \mathrm{~N}$ resulted in the lowest RS (24.9 mg.g $\left.\mathrm{g}^{-1} \mathrm{DM}\right)$ and the dose of $40 \mathrm{~kg} \cdot \mathrm{ha}^{-1} \mathrm{~N}$ in the lowest content of TSS (51.8 mg.g $\left.{ }^{-1} \mathrm{DM}\right)$, whereas the highest levels of RS and TSS occurred at $75 \%$ of FC with absence of $\mathrm{N}\left(56.9 \mathrm{mg} \cdot \mathrm{g}^{-1} \mathrm{DM}\right)$ and $120 \mathrm{~kg} \cdot \mathrm{ha}^{-1}\left(91.8 \mathrm{mg} \cdot \mathrm{g}^{-1}\right.$ $\mathrm{DM})$, respectively. As occurred with the stolon, the water regime of $25 \%$ of $\mathrm{FC}$ provided the lowest concentrations of carbohydrates, especially of RS.

Melo et al. (2007) also observed decrease in the concentration of soluble sugars in the leaves and roots under water stress, which would be an indicative of a low osmoregulatory capacity of the species and of maintenance of survival with low consumption of these molecules.

The saccharose contents (Figure 4C) were higher under higher conditions of water deficiency, which can be related to the osmotic effect that these carbohydrates can cause. The accumulation of solutes can result in the capacity of plants to tolerate drought, since they help prevent water loss and keep the cell turgor, due to the osmotic effect. Among these solutes, proline, saccharose and oligosaccharides stand out (Tamura et al., 2003; Reddy et al., 2004). Alterations in the levels of these metabolites are associated with functions of cellular protection or with the maintenance of the structure of cell components (Seki et al., 2007).

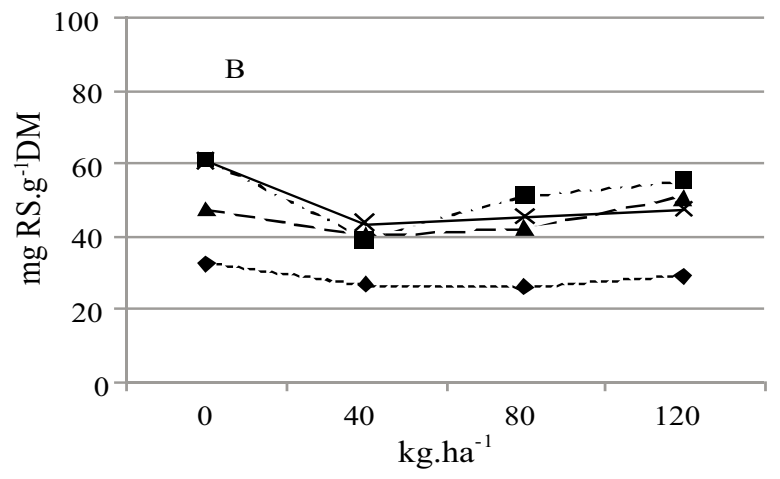

DM - dry matter; FC - field capacity.

Figure 4 - Total soluble sugars (TSS; A), reducing sugars (RS; B) and saccharose (SAC; C) in the roots of Arachis pintoi cv. Belmonte, cultivated under different water regimes and nitrogen doses, according to the following equations: TSS $=35.846-0.296 * \mathrm{~N}+$ $0.00357 * \mathrm{~N}^{2}+1.0612 * \mathrm{FC}-0.00702 * \mathrm{FC}^{2}(* \mathrm{P}<0.05)$, with $\mathrm{R}^{2}=0.61 ;$ and $\mathrm{RS}=12.112-0.353 * \mathrm{~N}+0.00272 * \mathrm{~N}^{2}+1.158 * \mathrm{FC}-$ $0.00749 * \mathrm{FC}^{2}(* \mathrm{P}<0.05)$, with $\mathrm{R}^{2}=0.71$. 

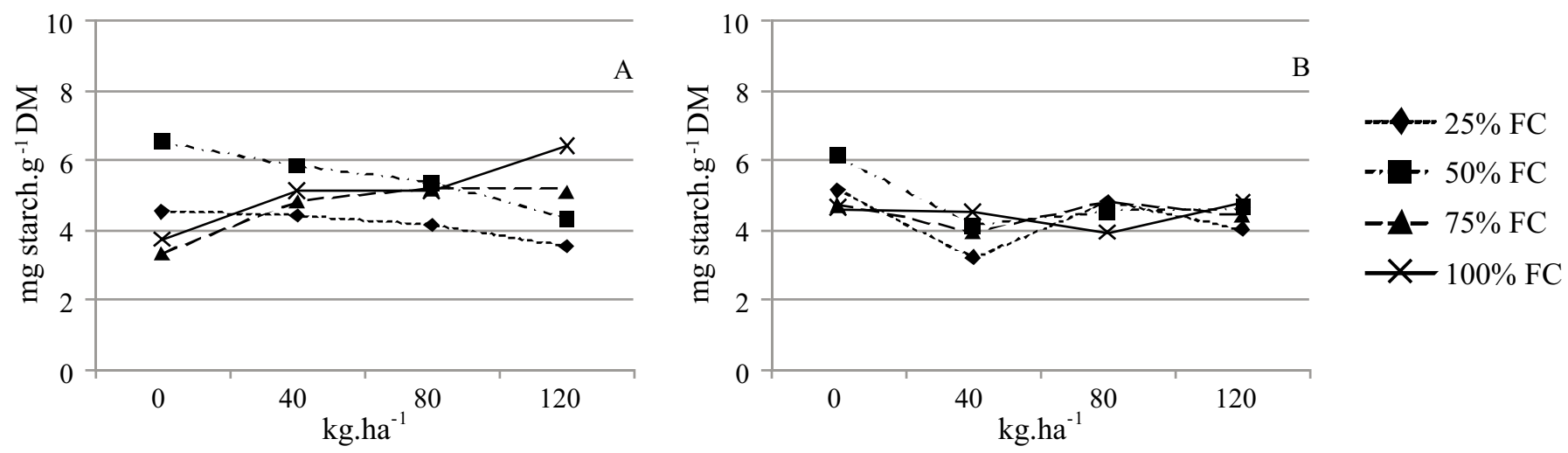

DM - dry matter; FC - field capacity.

Figure 5 - Starch levels in the stolon (A) and roots (B) of Arachis pintoi cv. Belmonte, cultivated under different water regimes and nitrogen doses, according to the following equations: starch in stolon $=5.969-0.0272 * \mathrm{~N}-0.0202 * \mathrm{FC}+0.000465 * \mathrm{NFC}(* \mathrm{P}<0.05)$, with $\mathrm{R}^{2}=0.89 ;$ and starch in roots $=4.992-0.0261 * \mathrm{~N}+0.000186 * \mathrm{~N}^{2}+0.000588 \mathrm{FC}(* \mathrm{P}<0.05)$, with $\mathrm{R}^{2}=0.87$.

The interaction between water regime and $\mathrm{N}$ doses was significant for the starch content of the stolon of forage peanut. In more appropriate water conditions ( 75 and 100\% of FC), the presence of $\mathrm{N}$ generated larger contents of starch in the stolon, with the highest level observed at the dose of $120 \mathrm{~kg} \mathrm{~N} \cdot \mathrm{ha}^{-1}$ and $100 \%$ of field capacity $\left(8.3 \mathrm{mg} \cdot \mathrm{g}^{-1}\right.$ glucose in DM) (Figure 5).

A drop in the concentration of starch is usually observed under water shortage conditions, so it is an indicative of consumption of these sugars for the maintenance of plant survival (Melo et al., 2007).

The starch content of roots responded quadratically to the $\mathrm{N}$ doses (Figure 5). The highest contents $\left(5.0 \mathrm{mg} . \mathrm{g}^{-1}\right.$ glucose in DM) were found both in the absence of $\mathrm{N}$ and at the dose of $1210 \mathrm{~kg} \cdot \mathrm{ha}^{-1}$. The quadratic effect of $\mathrm{N}$ can be a result of the smaller development of roots in the presence of high doses of N. According to Bélanger et al. (1992), the increase in $\mathrm{N}$ boosts the growth of the shoots of the plant over the roots.

\section{Conclusions}

The presence of nitrogen increases the contents of total chlorophyll and chlorophylls $a$ and $b$ of Arachis pintoi cv. Belmonte, affecting growth, especially of shoots. Doses of 120 kg.ha ${ }^{-1}$ of nitrogen promote higher levels of saccharose in the roots at low water availability.

\section{References}

ALVAREZ V., V.H.; RIBEIRO, A.C. Calagem. In: Comissão de Fertilidade do Solo do Estado de Minas Gerais. (Ed.) Recomendações para o uso de corretivos e fertilizantes em Minas Gerais. $5^{\text {a }}$ aproximação, Viçosa, MG: CFSEMG, 1999. p.41-60.
ARNON, D.I. Cooper enzymes in isolated chloroplasts polyphenol oxidase in Bet vulgaris. Plant Physiology, v.24, n.1, p.1-15, 1949.

BÉLANGER, G.; GASTAL, F.; WAREMBOURG, F. The effects of nitrogen fertilization and the growing season on carbon portioning in a sward of tall fescue. Annals of Botany, v.70, p.239-244, 1992.

BENETT, C.G.S.; BUZETTI, S.; SILVA, K. et al. Produtividade e composição bromatológica do Capim-Marandu a fontes e doses de nitrogênio. Ciência e Agrotecnologia, v.32, n.5, p.1629-1636, 2008.

BLUM, A. Crop responses to drought and the interpretation of adaptation. Plant Growth Regulation, v.20, p.135-148, 1996.

CHAVES, M.M.; OLIVEIRA, M.M. Mechanisms underlying plant resilience to water deficits: prospects for water-saving agriculture. Journal of Experimental Botany, v.55, n.407, p.2365-2384, 2004.

CHYLINSKI, W.K.; LUKASZEWSKA, A. J.; KUTNIT, K. Drought response of two bedding plants. Acta Physiology Plant, v.29, p.399-406, 2007.

DISCHE, Z. General color reactions. In: WHISTLER, R.L.; WOLFRAM, M.L. (Eds.) Carbohydrate chemistry. New York: Academic Press, 1962. p.477-520.

EMPRESA BRASILEIRA DE PESQUISA AGROPECUÁRIA EMBRAPA. Centro Nacional de Pesquisa de Solos. Sistema brasileiro de classificação de solos. Brasília: Embrapa Produção da Informação; Rio de Janeiro: Embrapa Solos, 1999. $412 \mathrm{p}$.

GRATANI, L.; VARONE, L. Leaf key traits of Erica arborea L., Erica multiflora L. and Rosmarinus of ficinalis L. co-occuring in the Mediterranean maquis. Flora, v.199, p.58-69, 2004.

HAVAUX, M.; TARDY, F. Loss of chlorophyll with limited reduction of photosynthesis as an adaptive response of Syrian barley landraces to high-light and heat stress. Australian Journal of Plant Physiology, v.26, p.569-578, 1999.

JANK, L.; VALLE, C.B.; RESENDE, R.M.S. Novas alternativas forrageiras para pastagens tropicais. In: ZOOTEC, 21., 2005, Campo Grande. Anais... Campo Grande, 2005. 15p.

MELO, H.C.; CASTRO, E.M.; SOARES, A.M. et al. Alterações anatômicas e fisiológicas em Setaria anceps Stapf ex Stapf ex Massey e Paspalum paniculatum L. sob condições de déficit hídrico. Hoehnea, v.34, n.2, p.145-153, 2007.

MILLER, G.L. Use of dinitrosalicylicacidreagent for determination of reducing sugar. Analytical Chemistry, v.31, n.3, p.426-428, 1959. 
MIRANDA, C.H.B.; VIEIRA, A.; CADISCH, G. Determinação da fixação biológica de nitrogênio no amendoim forrageiro (Arachis spp.) por intermédio da abundância natural de ${ }^{15} \mathrm{~N}$. Revista Brasileira de Zootecnia, v.32, n.6, p.1859-1865, 2003.

RAMOS, A.K.B.; BARCELLOS, A.O.; FENANDES, F.D. Gênero Arachis. In: FONSECA, D.M.; MARTUSCELLO, J.A. (Eds.) Plantas forrageiras. Viçosa, MG: UFV, 2010. p.250-293.

REDDY, A.R.; CHAITANYA, K.V.; VIVEKANANDAN, M. Drought-induced responses of photosynthesis and antioxidant metabolism in higher plants. Journal of Plant Physiology, v.161, p.1189-1202, 2004.

SEKI, M.; UMEZAWA, T.; URANO, K. et al. Regulatory metabolic networks in drought stress responses. Current Opinion in Plant Biology, v.10, p.296-302, 2007.

SILVA, S.C. Desafios e perspectivas para a pesquisa e uso de leguminosas em pastagens tropicais: uma reflexão. In: ENCONTRO SOBRE LEGUMINOSAS: DESAFIO E
PERSPECTIVAS, 2., 2008, Nova Odessa. Anais... Nova Odessa, 2008. p. 163.

SILVA, S.C.; NASCIMENTO JÚNIOR, D.; EUCLIDES, V.B.P Pastagens: Conceitos básicos, produção e manejo. Viçosa, MG: Suprema, 2008. p.24-29.

TAIZ, L.; ZEIGER, E. Fisiologia vegetal. 4.ed. Porto Alegre: Artmed, 2009. p.95-102.

TAMURA, T.; HARA, K.; YAMAGUCHI, Y. et al. Osmotic stress tolerance of transgenic tobacco expressing a gene encoding a membrane located receptor-like protein from tobacco plants. Plant Physiology, v.131, p.454-62, 2003.

VALLIYODAN, B.; NGUYEN, H.T. Understanding regulatory networks and engineering for enhanced drought tolerance in plants. Current Opinion in Plant Biology, v.9, p.189-195, 2006.

XIAO, B.Z.; CHEN, X.; XIANG, C.B. et al. Evaluation of seven function- known candidate genes for their effects on improving drought resistance of transgenic rice under field conditions. Molecular Plant, v.2, p.73-83, 2009. 